\title{
THE CHALLENGES OF KNOWLEDGE CONSTRUCTION THROUGH E- MODERATING AT UNIVERSITAS TERBUKA, INDONESIA CASE STUDY: TUTORIAL ONLINE IN MATHEMATICS COURSES
}

\author{
Suroyo (suroyo@mail.ut.ac.id) \\ Atun Ismarwati (atun@mail.ut.ac.id) \\ Universitas Terbuka, Indonesia
}

\begin{abstract}
Implementation of Information and Communication Technology (ICT) in distance learning requires some efforts to succeed. Currently in using internet for learningassisted service, UT has utilized tutorial online for 171 courses. In the implementation of tutorial online UT found many constraints such as the number of students who use tutorial online facility is relatively small, low capability of using ICT, high cost, low accessibility, and technical difficulty. E-moderating is one of the learning approach to be used in evaluating tutorial online for two sample courses in Mathematics MATK4531- Structure of Algebra and MATA4350-Mathematics of Finance. Research on the implementation of the on-line tutorials indicates that the development stages of tutorial online could facilitate learning experiences but there are some difficulty in accessing and socializing the facilities for new students. The efforts to acquire learning effectiveness in Tutorial Online at UT should be creatively develop.
\end{abstract}

Keywords: distance learning, information and communication technology, knowledge construction

\section{RATIONALE}

In Europe perspectives (retrieved from Europa 12/7/2005), technological revolution in the United States is chiefly benefited the US economy. Doing business via internet made American companies much more efficient and productive. Between 1995 and 2001, the US economy grew, on average, by $3.67 \%$ per year-well ahead of Europe's $2.4 \%$ annual average over the same period. In Europe, GDP is only $65 \%$ of its level in the United States, and average labor productivity in Europe is also lower than in the US. Meeting in Lisbon in March 2000, the European Council set the EU a new and very ambitious goal: to become, within a decade, "most competitive and dynamic knowledge-based economy in the world, capable of sustainable economic growth with more and better jobs and greater social cohesion".

European as develop countries, Information and Communication Technology (ICT) is used to build Knowledge(-based) Society. The strategic goal for 2010 set for Europe at the Lisbon European Council (March 2000) preliminary stated that the fast development of the ICT has brought about deep changes in our way of working and living, as the widespread of ICT is accompanied by organizational, commercial, social and legal innovations. European society is now defined as the "information society", a society in which low-cost information and ICT are in 
general use, or as the "Knowledge(-based) Society", to stress the fact that the most valuable asset is investment intangible, human, social capital and that the key factors are knowledge and creativity.

Korea as one of the Asian countries, the issues and lessons for life long learning in the Knowledge-based Society stated by Hong (retrieved 12/7/2005) at International seminar cohosted by KRIVET (Korea Research Institute for Vocational Education \& Training) and IIEP/UNESCO (International Institute for Educational Planning) in Seoul that it is the opportunity to share the challenges and prospects faced by Asia and Europe pursuing the task of "Making Lifelong Learning a Reality" and it is a chance for scholars from the nations to gather together and share wisdom in order to make lifelong learning a reality. Based on the report by Jacques Delors emphasizes lifelong learning as the major scholastic direction that should pursued in the $21^{\text {st }}$ century, and suggest four main pillars of learning: Learning to know; Learning to do; Learning to be; Learning to live together. Korea is one of the countries that has seen the liveliest discussion about a knowledge-based society. Especially in the former government of President Kim Dae-Jung, knowledge was a key policy issue. A creative knowledge-based state, knowledge-based economy, knowledge-based society, knowledge management, knowledge workers, knowledge industry and new intellectuals were the paramount topics of conversation during this era. At that time, the knowledge-based society war regarded as a ray of light capable of leading Korea out of the dark tunnel of foreign exchange crisis.

In Open University of Malaysia, Muthusamy and Fadzil (2005) identified some criteria's for Elearning Delivery Platform (ELDP) for distance learning such as self-developed selection criteria, information provided by ELDP vendors, Open and Distance Learning (ODL) industry standard, articles, journal reports, seminars, proceedings and many other. Among these, the self-developed criteria are one of the key factors in choosing a suitable and reliable ELDP provider or developer that meets the organization requirement. Some of the recommended ELDP criteria's in ODL industry are cost, complexity (user focus), control, clarity, common technical framework, and feature (Belyk, 2002). Intelligent ODL pedagogy is one of the futurist aspirations to be achieved by an ODL institution. One of the intelligent features is the intelligent technique for managing collaborative learning.

Indonesia as developing country, according to Suryadi (2005), in educational reform for nations capacity building, Indonesia should consider to build communal intelligence in the society. Communal intelligence is societal collective intelligence which are build from individual intelligence who has capability to construct societal wisdom such as thinking capability, idealism, ethos, solidarity, creativity, political power, etc. In general, educational system should achieve at least five challenges aspects of educational outcome. The first challenge is character power development in the value and integrity of humankind. The second is leadership power development which need to be socialized in educational system as the basic of creativity, innovation , wisdom, and independence. The third is citizenship power development which can use societal heterogenity and culture as the power to develop "statebrand" in globalization. The fourth is thinking power development which provide a lot of thinking practice to enhance skills power in business capability for micro and macro economic 
growth. The fifth is engineering power development which support researches, innovation, and technological to build competitiveness among develop countries. For those challenges, according to Hamied (2005) educational system should have fundamental aspect capability to build knowledge based society. Human resource development needs such a program that toward the whole aspect of living, namely knowledge-based and borderless economy (KEconomy). In K-Economic era, competitiveness of the human resource can be determined from the use of knowledge in creating such innovations which have high economic added value. Information that globally accessible in high speed can be supported by using ICT.

Educational systems around the world are under increasing pressure to use the new information and communication technologies (ICTs) to teach students the knowledge and skills they need in the 21st century. The 1998 UNESCO World Education Report, Teachers and Teaching in a Changing World, describes the radical implications the new information and communication technologies have for conventional teaching and learning. It predicts the transformation of the teaching-learning process and the way teachers and learner gain access to knowledge and information.

In the use of internet for tutorial online at Universitas Terbuka-Indonesia, based on research result, the activity of graduate students $(N=15)$ in the field of management at Universitas Terbuka when they were login are reading (content and assignment $=75 \%$ ), down loading (content and assignment $=37.5 \%)$, discussion $(37.5 \%)$, finding additional references $(12,5 \%)$, resuming content (12.5\%), and doing assignment (12.5\%) indicate that the learner activities tend to use internet passively and facing the obstacles in other activities (Andriani, 2005). Computer-mediated Communication (CMC) as a model of learning in distance education, is one of the alternative ways to the challenges and E-moderating is further concept of CMC to facilitate collaborated learning in gather knowledge together (Salmon, 2000). Creating knowledge through distance learning needs some active efforts and creativity to reach instead of collaboration form the whole educational systems to grasp and develop ICT.

\section{THE TERMS TO APPROACH KNOWLEDGE CONSTRUCION}

\section{Building Knowledge-based Society}

Knowledge-based society can be define as "an innovative and lifelong learning society, which possesses a community of scholars, researchers, engineers, technicians, research networks, and firms engaged in research and in production of high-technology goods and service provision" (Work Science Forum, 2003). In global context as noted in the UNESCO World Educational Report, Teacher and Teaching in a Changing World (UNESCO, 1998), "the young generation is entering a world that is changing in all spheres: scientific and technological, political, economic, social, and cultural. The emergence of the 'knowledge-based' society is changing the global economy and the status of education". There is growing awareness among policy-makers, business leaders and educator that the educational system designs to prepare learners for an agrarian or industrial-based economy will not provide students with knowledge and skills, they will need to thrive in $21^{\text {st }}$ century's knowledge-based economy and society. The new knowledge-based global society is one in which: 1) the world's knowledge doubles every 2-3 years; 2) 7,000 scientific and technical articles are publish each day; 3) data 
sent from satellites orbiting the earth transmit enough data to fill 19 million volumes every two weeks; 4) graduates of secondary school in industrialized nations have been exposed to more information than their grandparents were in a lifetime; 5) there will be as much change in the next three decades as there was in the last three century (National School Board Association, 2002). Application of collaborative instructional strategy which acquire response from educational society such as teachers, students, parents, and computer programmers should be considered as the challenges for building of learning-based society and needs to be widening and responding from the educational experts and institutions that concern in developing education and assessment (Ismarwati, et al., 2005).

\section{The Experience of Learning}

The challenge confronting educational systems is how to transform the curriculum and teaching-learning process to provide students with the skills to function effectively in this dynamic, information-rich, and continuously changing environment. Skill in learning and organizing knowledge can be achieved from deep and surface approach which emphasized referential aspects of students experiences-their search for meaning or not, while the other achieved from holistic and atomic approach which concerned organizational aspects-the ways in which they organized the informational content of the article in their reading (Marton \& Saljo, 1997; Svensson, 1976). Within those approaches, difference between people in their ways of organizing materials are distinguished. An important change which take place when one moves through successive levels of the educational system from primary school to higher education concerns the learning tasks dealt with. The knowledge and the phenomena which students are required to deal with increase in scope and complexity (Svensson, 1997). In the conclusion, Svennson conclude that skill in studying is not equivalent to the skill in learning. More over, the benefits of skilled learning go beyond a better knowledge of a specific body of subject-matter ant its long-term retention an application to new material. Ultimately, improvements in skill in learning which stem from any particular course unit are not specific to the content of that unit. They are improvements in the skill of understanding and learning to learn, The student becomes more skilled at extending his or her understanding through an exploration of new and more complex material. Define in this way, learning requires a relative absence of stress and a confidence in one's own thinking that are not always fostered in educational systems.

\section{The Conditions of Learning}

In human learning, theory that presents a systematic integration at many theories of human learning is advanced by Robert Gagne. He claims that people learn in many ways, including simple Pavlovian conditioning, Skinnerian conditioning, and other cognitive processes. The various ways of learning are most clearly evident in different outcomes of learning process. Gagne (1985) describes five major outcomes of learning in terms of domain of learning capabilities: (1) intellectual skills are concerned with the how of learning, the other four domain are concern more with the what of learning; (2) verbal information, (3) attitudes, (4) motor skills, and (5) cognitive strategies. From constructivism perspective, The world is not found or discovered, Bruner and Piaget, psychologists, claim that it is constructed. Constructivism is a model of the learner as a builder of knowledge. In more recent model of the learner, Bruner (1985) suggested one approach from the practical business of taking learners who are novices 
and making experts out of them. The novice-to-expert model is evident in informationprocessing approaches that use computers to stimulate aspects of learning. In contrast with other models, the novice-to-expert model tends to be domain-specific rather than general. The stages of the condition of learning is illustrated in Figure 1.(a).

\section{Constructivist Learning Design}

Constructivist Learning Design (CLD) which embodies Gagnon and Collay's foundation concepts, refers specifically to assumption that humans develop by engaging in the personal and social construction of knowledge. Humans make personal meanings and create shared meanings with others. Thus, humans construct knowledge; we do not receive and internalize predigested concepts without simultaneously reacting and engaging within mental maps and previous experiences. Learning signifies that the primary goal of schooling is student development and improvement. Teaching should be but one means to that end and as such is secondary in importance to it. Design denotes the overall structure and outline, sequence of parts, and general forms through which educational activities flow. Furthermore Gagnon and Collay compose six basic parts flowing back and forth into one another in the actual operation of classroom learning: (1) situation which frames the agenda for students engagement by delineating the goal, task, and forms of the learning episode; (2) groupings are the social structures and group interactions that will bring students together in their involvement with the tasks and form of the learning episode; (3) bridge refers to the surfacing of the students' prior knowledge before introducing them to the subject matter; (4) question aim to instigate, inspire, and integrate students thinking and sharing information during a learning episode; (5) An exhibit asks students to present publicly what they have learned (artifacts of learning); (6) reflections offer students and teachers opportunities to think and speak critically about their personal and collective learning to look ahead to the future learning episodes (Gagnon \& Collay 2001). In knowledge construction, it is valuable to develop attitude to give appreciations for anyone who give contributions in developing better and usable online instructional system of ICT (Suroyo, et al. 2005:9). Sample case in CLD concepts are summarized in Table 1. and relationship among CDL elements is illustrated in Figure 1 (b).

\section{Open and Distance Education}

The term of open and distance Education, according to More (2003), some of the terms that will be found in handbooks (e.g. tele-learning and e-learning) emphasize the use of a particular communication technology, others (distribute learning and distant learning) focus on learners, others (open learning and flexible learning) point out the relative freedom of distance learners to exercise more control over their learning than normal in conventional education. By emphasizing a particular feature of distance learning, such terms are valuable, but those terms are not synonymous for distance education itself. These are all different aspects of distance education, defined as " all forms of education in which all or most of the teaching conducted in a different space than the learning, with the effect that all or most of the communication between teachers and learners is through a communications technology." Thus distance education is the generic terms, and other terms express subordinate concepts. 


\title{
Table 1. Summarizing of CDL Concepts
}

\author{
Case Study : Structures of Algebra and Mathematics of Finance \\ Level : Higher Education \\ Subject $\quad:$ CLD in the courses of Structures of Algebra and Financial Mathematics \\ Title : Compound Interest \\ Designers : : George W. Gagnon Jr. and Michelle Collay \\ Tutors : : Atun Ismarwati and Suroyo
}
Situation Problem, experience, event, and phenomenon before settling on situation. Specific purpose, present an open-ended task to accomplish, compels interest by challenging students, connects student learning to real-world experience.
Teachniques for situations: Framing tasks as real-life experiences, deriving rules from examples, tweaking textbooks, unpacking assumptions
Grouping Small group share meaning in social construction of knowledge
Teachniques for groupings: commiting to using group process or cooperative learning, random or ability grouping, using materials to make thinking visible.

Bridge Before beginning any new learning, tutor can surface the prior knowledge. It serves as the foundation for bridge between what student already know and the new learning they will engage in during a learning episode (Shullman, 1999). Surface students' prior knowledge, refocuses students, organizes students into collaborative groups, built community between students, creates a shared understanding and vocabulary, gather information about what each student know.

Teachniques for bridges: engineering bridges (taking time to find out what some students know and what others don't know can surface valuable resources for all students), people bridges ( doing the bridge in small groups gives students an opportunity to meet peers can give valuable information about the strengths and weaknesses of group members), floating bridges (familiarize students understand, then surfacing prior knowledge to connect new learning might be accomplished quickly).

Question Question can be used to introduce the situation, arrange grouping, set up the bridge, support active learning, prompt exhibit, and encourage reflections. Questions categories: (1) Guiding questions (setting up the situation or bridge); (2) Anticipated questions from the students to frame responses that encourage students to explain their thinking or support in continuing to think for themselves; (3) Clarifying questions are often responses to student request for information or explanation as they work to accomplish the task present in the situation; (4) Integrating questions are typically asked to provoke students to synthesize their thinking for an exhibit or reflections an the learning episode is coming to closure.

Teachniques for question: asking the right question (set the tone for engaging the students in their own thinking and learning), it feels good to give answers (enjoy knowing something and being able to share it with another person), sometimes a small change causes big confusion (use a familiar situation), twominute warning (usually take temperature of working groups by announcing a two minutes warning when most seem ready to present).

Exhibit Students: generate artifacts to document their accomplishment of a task, present their artifacts publicly and explain their thinking, respond to questions from tutor or peers

Tutor. guide student considerations of learning episode, align student explanations of thinking with requirement of state or national standard.

Teachniques for exhibits: Recording and reporting thinking, using the record of thinking, teaching to learn, keeping a positive tone, valuing and encouraging divergent thinking, identifying exhibit in the real world.

Reflection Critical element offers both students and tutor the opportunity to think again about individual and collective learning to begin the integration of new knowledge with existing knowledge, and in many cases, to design strategies for next learning episode.

Tutor: lead a collective consideration of learning episodes, gather data about individual students' understanding, connect the learning episode to big ideas and address common misconceptions.

Students: individually consider their thinking during learning episode, record their thinking to document learning, revisit their thinking after the learning episode. 


\section{Tutorial Online}

The term 'online' came from the days of the telegraph, when messages could be tapped directly onto the line rather than prepared 'offline' on perforated tape, for sending when the machine was connected later to the telephone line. Today, 'online' covers a range of technologies. In education and training, technologies that concentrate on computer- mediated communication (CMC) are commonest (Salmon, 2000). Students' experience of learning and teaching within tutorial groups in more appropriately represented by recognizing the ways in which their understanding of a discipline is both simultaneously enabled and constrained by their tutors. Yet, tutors are, at the same time, enabling novice to gain new framing perspectives on topics and so develop their abilities (Anderson, 1997).

\section{Computer-Mediated Communication}

Computer Mediated Communication (CMC) is a generic term commonly used for a variety of systems that enable people to communicate with other people by means of computer and networks. In the work environment, a common and growing phenomenon is collaborative work by individuals or groups who are separated from each other by either time or distance. In the education and training context, in addition to computer 'conferencing,' we can set up computermediated discussion of a more-focused nature as exemplified by so-called virtual classroom, computer-mediated seminars and case study discussions, and computer-mediated job 'performance support systems' (Romiszowski \& Mason, 1996).

\section{Model of CMC E-Moderating}

E-moderating model developed by Salmon (2002) consists of five stages illustrated in Figure 1. (1) access and motivation (for e-moderators and students alike, being able to gain access quickly and easily to the CMC system, the other is being motivated to spend time and effort); (2) online socialization (CMC offers the 'affordance' which means the technology enables or creates the opportunity of online socializing and networking); (3) information exchange (for participants, their learning requires two kinds of interaction: interaction with the course content and interaction with people, namely the e-moderator(s) and other participants; (4) knowledge construction (participants write down their ideas or understanding of a topic and engage in some very active learning, especially through widening their own viewpoints and appreciating different perspectives); (5) development (participants become responsible for their own learning through computer-mediated opportunities and need little support beyond that already available).

\section{CMC E-Moderating in Mathematics Teaching}

In mathematics teaching, Oldknow and Taylor (2003) analyzed that there are at least three possible reasons for promoting the integration ICT in mathematics teaching in schools: (1) desirability for students may: engage attention and motivation, stimulate curiosity, encourage to develop problem solving strategies, provide models and images in concept formation aid, improve test and examination results, etc.; for teachers may: improve their efficiency, reduce administrative burden, release more time to address students individually, provide better records of students' progress, be a stimulus to re-thinking approach to mathematics teaching, be a stimulus to re-thinking understanding of mathematics, be a means to communicate with 
other teachers sharing common problem etc.; for schools may: improve efficiency and reduce teaching cost, improve examination results and the school's position in 'league tables', improve educational inclusion, reduce truancy, social disruption, etc., improve provision for students who are not learning in their native tongue, etc.; (2) inevitability where the conventional alternatives no longer exist, prohibitively expensive, or impose such obvious restrictions that their use cannot be rationally supported; (3) public policy in UK is concerned there has been a remarkably consistent acceptance of the educational benefits of ICT over the past twenty years, irrespective of which political party has been in power nationally or locally.

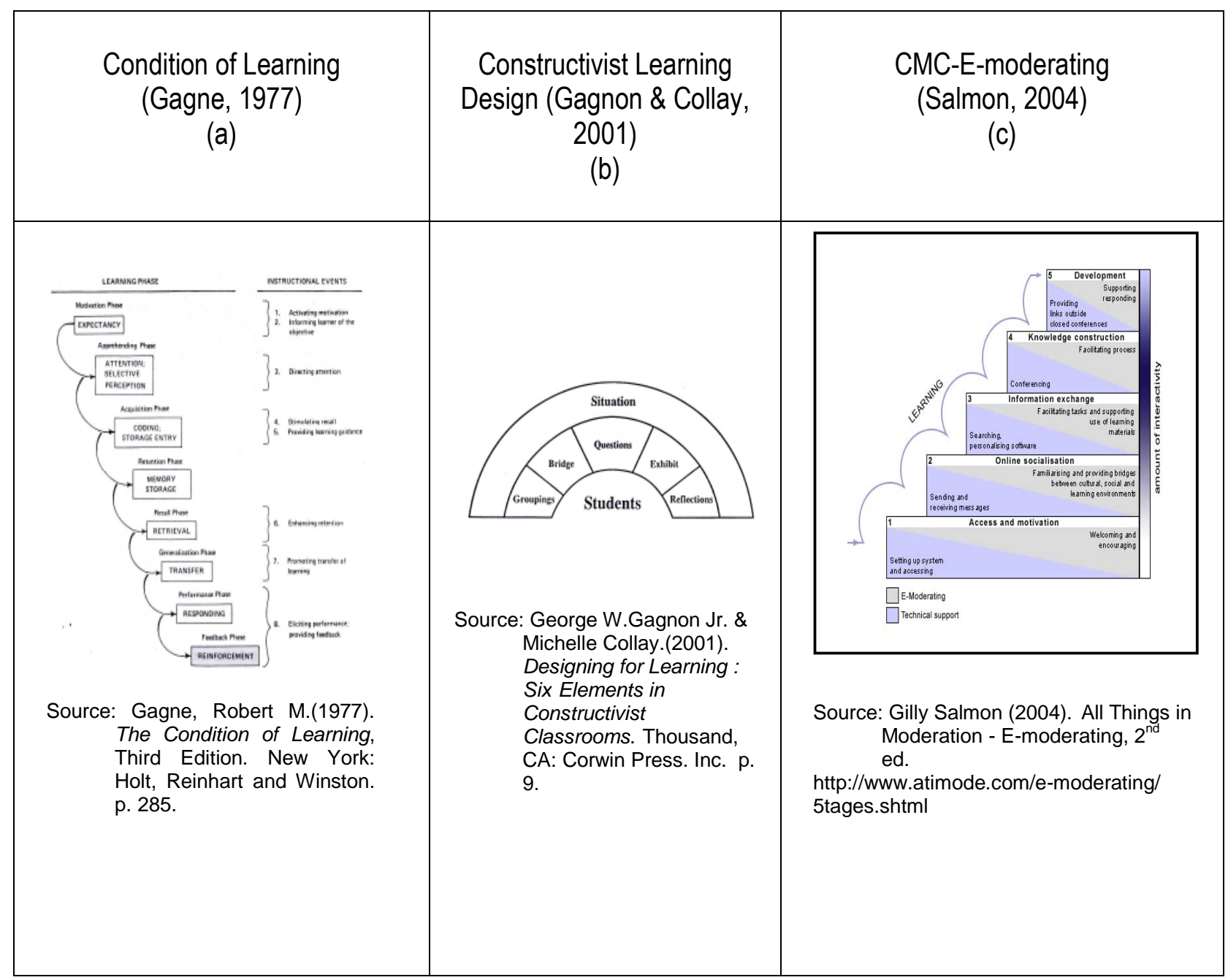

Figure 1. Approaches of Learning Theory in Knowledge Construction 
Universitas Terbuka (UT) that uses distance learning systems has been implementing ICT based on technological availability for more than 20 years. Three main components of using ICT are providing learning materials, learning-assisted service, and conducting examination. Currently in using internet for learning-assisted service, UT has utilized tutorial online for 171 courses. In the implementation of tutorial online UT found many constraints such as: the number of students who use tutorial online facility is relatively small and low interest, low capability of using ICT, highly cost, accessibility, and technical difficulty (Eduard, Patria \& Sufandi, (2005:1), as the challenges to break the obstacles, in accordance to achieve UT's vision to be one of the centers of excellence among distance education institutions in Asia by 2010 and in the world by 2020 (Dimyati, 2005). In selecting technology and media, Hardhono (2005) uses ACTIONS criteria (Tony Bates, 1990) the acronym of Accessibility, Cost: fixed \& variable, Teaching \& Learning effectiveness, Interactivity (how far and deep it involves students in learning), Organization (who are involved in development, Novelty, and Speed (how fast revision can be made), UT needs efforts to grasp new technology for ICT by using such technology as Multicast IPV6 and further next available technology to develop ICT. UT should consider to use many approaches and strategies creatively to build communal intelligence in the learning systems at least by novice-to-expert approach to construct knowledge for societal wisdom such as thinking capability, idealism, ethos, solidarity, collaboration, creativity, and political power. UT uses software Moodle to facilitating tutorial online which can be utilized to develop education and training based internet. Based on Tutorial Online Technical Guidance for Tutors (2005), the homepage address is http://tutor.ut.ac.id . Moodle is designed for supporting social construct framework in education. Moodle is one of the models of CAL+CAT (Computer Assisted Learning+Computer Assisted Teaching) called LMS (Learning Management System)

\section{IMPLEMENTATION OF E-MODERATING IN MATHEMATICAL COURSES}

In evaluating the implementation of ICT in tutorial online programs at UT, there are some references developed from learning approaches such as Conditions of Learning (Gagne, 1985), Constructivist Learning Design (Gagnon \& Collay, 2001), and Computer-mediated Communication E-Moderating (Salmon, 2004) compared with stages of utilizing Tutorial Online. The objectives of the evaluation are knowledge construction and learning outcome.

Case Studies in the implementation of CMC-E-moderating for Tutorial Online are MATA4321Structure of Algebra Course (2004.1/2004.2) and MATA4350- Mathematics of Finance Course (2005.1/2005.2) in the Department of Mathematics at UT. The results are presented in Table 1, Table 2, and Figure 2. 
Table 1. Evaluation of Tutorial Online based on Learning Approaches

\begin{tabular}{|c|c|c|c|c|c|c|}
\hline \multirow[t]{2}{*}{ Stage } & \multicolumn{2}{|c|}{$\begin{array}{c}\text { Conditions of Learning } \\
\text { Gagne (1985) }\end{array}$} & \multirow{2}{*}{$\begin{array}{c}\text { CLD } \\
\text { Gagnon \& } \\
\text { Collay (2001) }\end{array}$} & \multirow{2}{*}{$\begin{array}{c}\text { CMC } \\
\text { E-moderating } \\
\text { Salmon (2004) }\end{array}$} & \multicolumn{2}{|c|}{$\begin{array}{c}\text { Tutorial Online at UT (2005) } \\
\text { (Mathematics of Finance) }\end{array}$} \\
\hline & Learning Phase & $\begin{array}{l}\text { Instructional } \\
\text { events }\end{array}$ & & & Weeks & Initiations \\
\hline \multirow{3}{*}{1} & \multirow{3}{*}{ Motivation } & $\begin{array}{l}\text { Activating } \\
\text { motivation }\end{array}$ & \multirow{3}{*}{ Situation } & \multirow{3}{*}{$\begin{array}{l}\text { Access and } \\
\text { motivation }\end{array}$} & \multirow[t]{3}{*}{1} & $\begin{array}{l}\text { Tutorial Online } \\
\text { Activation }\end{array}$ \\
\hline & & \multirow{2}{*}{$\begin{array}{l}\text { Informing } \\
\text { learner of the } \\
\text { objectives }\end{array}$} & & & & Introduction \\
\hline & & & & & & Lesson plan \\
\hline 2 & Apprehending & $\begin{array}{l}\text { Direct } \\
\text { attention }\end{array}$ & Grouping & $\begin{array}{l}\text { Online } \\
\text { socialization }\end{array}$ & 2 & $\begin{array}{l}\text { Problems } \\
\text { Mapping } \\
\text { (module 1-9) }\end{array}$ \\
\hline \multirow[t]{2}{*}{3} & \multirow[t]{2}{*}{ Acquisition } & $\begin{array}{l}\text { Stimulating } \\
\text { recall }\end{array}$ & Bridge & \multirow{2}{*}{$\begin{array}{l}\text { Information } \\
\text { exchange }\end{array}$} & \multirow[t]{2}{*}{3} & $\begin{array}{l}\text { Discussion } \\
\text { (module 1-3) }\end{array}$ \\
\hline & & $\begin{array}{l}\text { Providing } \\
\text { learning } \\
\text { guidance }\end{array}$ & Question & & & $\begin{array}{l}\text { Task } 1 \\
\text { (module 1-3) }\end{array}$ \\
\hline \multirow[t]{8}{*}{4} & \multirow[t]{2}{*}{ Retention } & \multirow{4}{*}{$\begin{array}{l}\text { Enhancing } \\
\text { retention }\end{array}$} & \multirow{8}{*}{ Exhibit } & \multirow{8}{*}{$\begin{array}{l}\text { Knowledge } \\
\text { construction }\end{array}$} & \multirow[t]{2}{*}{4} & $\begin{array}{l}\text { Solution of Task } \\
1\end{array}$ \\
\hline & & & & & & $\begin{array}{l}\text { Discussion } \\
\text { (module 4,7,8) }\end{array}$ \\
\hline & \multirow[t]{2}{*}{ Recall } & & & & & $\begin{array}{l}\text { Discussion } \\
\text { (module 5) }\end{array}$ \\
\hline & & & & & 5 & $\begin{array}{l}\text { Task } 2 \\
\text { (module 5) }\end{array}$ \\
\hline & \multirow{4}{*}{ Generalization } & \multirow{4}{*}{$\begin{array}{l}\text { Promoting } \\
\text { transfer of } \\
\text { learning }\end{array}$} & & & 6 & $\begin{array}{l}\text { Solution of Task } \\
2\end{array}$ \\
\hline & & & & & & $\begin{array}{l}\text { Discussion } \\
\text { (module 6) }\end{array}$ \\
\hline & & & & & 7 & $\begin{array}{l}\text { Discussion } \\
\text { (module 9) }\end{array}$ \\
\hline & & & & & & $\begin{array}{l}\text { Task } 3 \\
\text { (module 9) }\end{array}$ \\
\hline \multirow[t]{3}{*}{5} & Performance & $\begin{array}{l}\text { Eliciting } \\
\text { performance }\end{array}$ & \multirow{3}{*}{ Reflection } & \multirow{3}{*}{ Development } & \multirow{3}{*}{8} & $\begin{array}{l}\text { Solution of Task } \\
3\end{array}$ \\
\hline & \multirow[t]{2}{*}{ Feedback } & \multirow[t]{2}{*}{$\begin{array}{l}\text { Providing } \\
\text { feedback }\end{array}$} & & & & $\begin{array}{l}\text { Summary } \\
\text { (discussions } \\
\text { scope) }\end{array}$ \\
\hline & & & & & & $\begin{array}{l}\text { Enrichment } \\
\text { (complementary) }\end{array}$ \\
\hline
\end{tabular}

Evaluation in Table 1. shows that the stages of tutorial online at UT approximately follow the stages of the theories of learning approach. 
Table 2. Comparison of Tutorial Online for MATA4321-Structure of Algebra (2004.1/2004.2) and MATA4350- Mathematics of Finance (2005.1/2005.2) in the Department of Mathematics at UT.

\begin{tabular}{|c|c|c|}
\hline Weeks & $\begin{array}{c}\text { MATK4531- Structure of Algebra } \\
(2004.1 / 2004.2) \\
\text { Tutor : Atun Ismarwati }\end{array}$ & $\begin{array}{c}\text { MATA4350- Mathematics of Finance } \\
(2005.1 / 2005.2) \\
\text { Tutor : Suroyo }\end{array}$ \\
\hline 1 & $\begin{array}{l}18 \text { Sept. -24 Sept. } \\
\text { Structures of Algebra and Groupoid } \\
\text { (module 5, learning activity 1) }\end{array}$ & $\begin{array}{l}18 \text { Sept. }-24 \text { Sept. } \\
\text { Mathematical applications in economics and daily } \\
\text { life. }\end{array}$ \\
\hline 2 & $\begin{array}{l}25 \text { Sept.-1 Oct. } \\
\text { Cayley List and Closed operations } \\
\text { (module 5, learning activity 2) }\end{array}$ & $\begin{array}{l}25 \text { Sept.-1 Oct. } \\
\text { Map of problems in mathematics of Finance } \\
\text { (module 1-9) }\end{array}$ \\
\hline \multirow[t]{2}{*}{3} & $\begin{array}{l}2 \text { Oct. - } 8 \text { Oct. } \\
\text { Groupoid attributes and wider Cayley } \\
\text { list } \\
\text { (module 6) }\end{array}$ & $\begin{array}{l}2 \text { Oct. }-8 \text { Oct. } \\
\text { Measurement for Simple interest and Compound } \\
\text { interest } \\
\text { (module 1-3) }\end{array}$ \\
\hline & & $\begin{array}{l}\text { Task } 1 \text { Determine accumulation and amount } \\
\text { functions }\end{array}$ \\
\hline \multirow[t]{2}{*}{4} & $\begin{array}{l}9 \text { Oct. }-15 \text { Oct. } \\
\text { Semigroups and Monoids } \\
\text { (module } 7 \text { ) }\end{array}$ & $\begin{array}{l}9 \text { Oct. - } 15 \text { Oct. } \\
\text { Annuity-certain and life-annuity payments. } \\
\text { (module 4,7,8) }\end{array}$ \\
\hline & Task 1 & Solution of task 1 \\
\hline \multirow[t]{2}{*}{5} & $\begin{array}{l}16 \text { Oct. - } 22 \text { Oct. } \\
\text { Quasi-Groups and Loops Concepts } \\
\text { (module 8) }\end{array}$ & $\begin{array}{l}16 \text { Oct. }-22 \text { Oct. } \\
\text { Amortization schedule and sinking funds } \\
\text { (module } 5 \text { ) }\end{array}$ \\
\hline & & $\begin{array}{l}\text { Task 2. Finding the outstanding loan balance: } \\
\text { remaining loan indebtedness and sinking funds }\end{array}$ \\
\hline \multirow[t]{2}{*}{6} & $\begin{array}{l}23 \text { Oct. }-29 \text { Oct. } \\
\text { Task } 2\end{array}$ & $\begin{array}{l}\text { bonds } 23 \text { Oct. }-29 \text { Oct. } \\
\text { Prices and value and other securities. } \\
\text { (module 6) }\end{array}$ \\
\hline & & Solution of task 2 \\
\hline \multirow[t]{2}{*}{7} & & $\begin{array}{l}30 \text { Oct.- } 5 \text { Nov. } \\
\text { Various kinds and forms of life insurance. } \\
\text { (module } 9 \text { ) }\end{array}$ \\
\hline & & $\begin{array}{l}\text { Task 3. Calculating benefits of value, expenses, } \\
\text { premiums, and endowment. }\end{array}$ \\
\hline \multirow[t]{3}{*}{8} & & $\begin{array}{l}6 \text { Oct. }-12 \text { Nov. } \\
\text { Summary }\end{array}$ \\
\hline & & Solution of task 3 \\
\hline & & Conclusion and enrichment \\
\hline
\end{tabular}

Comparison in Table 2 shows that the increasing of tutorial online activities from 6 weeks in the semester of 2004.1/2004 to 8 weeks in the semester of 2005.1/2005.2. The students activities in tutorial online are illustrated in Figure 2. 


\begin{tabular}{|c|c|c|}
\hline Activities & $\begin{array}{c}\text { MATK4531- Structure of Algebra } \\
\text { (2004.1/2004.2) } \\
\text { Tutor : Atun Ismarwati } \\
\text { (a) }\end{array}$ & $\begin{array}{l}\text { MATA4350- Mathematics of Finance } \\
\text { (2005.1/2005.2) } \\
\text { Tutor : Suroyo } \\
\text { (b) }\end{array}$ \\
\hline Access & (n) & 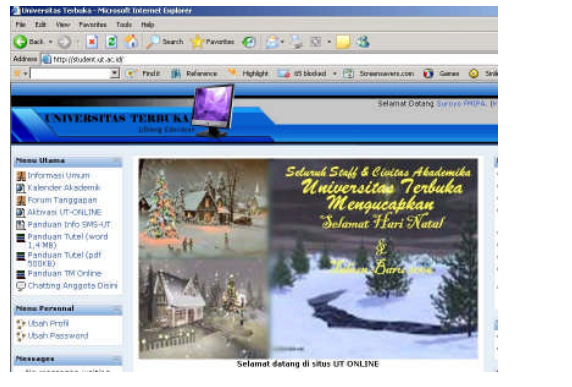 \\
\hline Grouping & 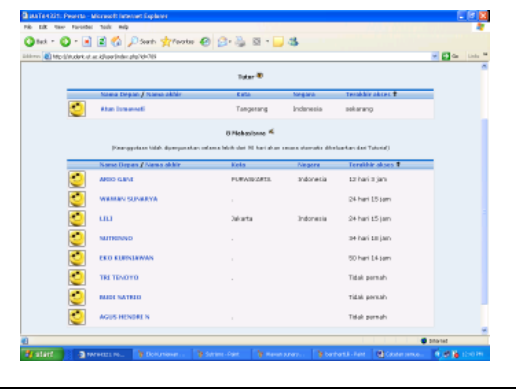 & 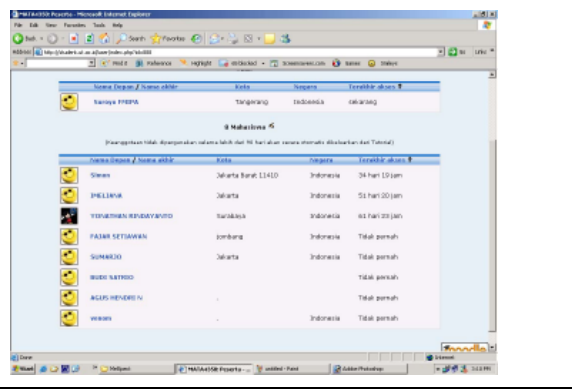 \\
\hline \multirow[b]{2}{*}{ Login } & 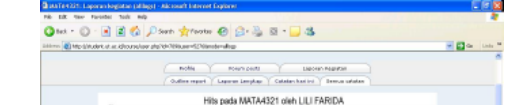 & 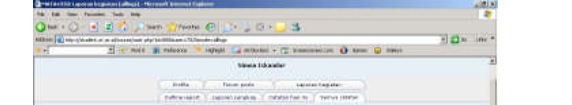 \\
\hline & 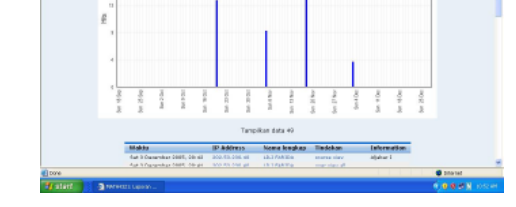 & 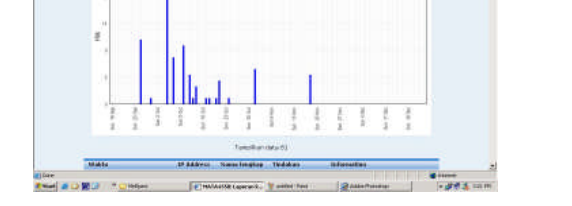 \\
\hline
\end{tabular}

Figure 2. Students Activities in Tutorial Online for MATA4321-Structure of Algebra (2004.1/2004.2) and MATA4350- Mathematics of Finance (2005.1/2005.2) in the Department of Mathematics at UT.

Figure 2. shows comparison of students activities in tutorial online activities for 6 weeks for (a) MATA4321-Structure of Algebra (2004.1/2004) and 8 weeks for (b) MATA4350- Mathematics of Finance (2005.1/2005.2). 1) Students' access: (a) 5 of 8 students (62.5\%) and (b) 3 of 8 students (37.5\%); 2) Time range of Login: (a) 12 days 3 hours to 50 days 14 hours and (b) 34 days 19 hours to 61 days 23 hours; 3 ) Scores: (a) 5 students (20) 3 students (0); (b) 1 student (60), 2 students (20), and 5 students (0). 


\section{CONCLUSIONS AND RECOMMENDATIONS}

Based on 5 stage of CMC E-moderating model, it can be concluded that:

1. First stage: Access and Motivation are considered still in low level, the challenge is to simplify the menu for novice to easy access and to promote the benefits of using tutorial online for learning experience and knowledge construction.

2. Second stage: Online socialization, the grouping has not seen from sending and receiving messages, the challenge is to provide bridge in network for communication online and to facilitate learning online environment for learning experiences as a chance to be part of knowledge-based society.

3. Third stage : Information exchange has not work well, yet, and the challenge is to create tasks which will encourage students to interact with course content and other students.

4. Fourth stage : Knowledge construction has some difficulty for the students to use forum menu in facilitating process to built knowledge especially to write down mathematical equations by using word processing, the challenge is to create guidance in writing down mathematical opinions for tutors and students involvement in E-moderating.

5. Fifth stage : Development is still need to improve in providing links outside closed conferencing, the challenge is to develop attitude of participants in the implementation of E-moderating to become responsible for their own learning through computer-mediated opportunities.

Realize that it is not easy to implement ICT for educational purposes, CMC E-moderating model can be used to direct and evaluate the achievement of knowledge construction for students and tutors who learn and teach in distance education as small number of peoples in the society and step by step build knowledge together through ICT. To achieve that goals, the words such as effort, motivate, active, support, creative, innovative, appreciative, effective, responsive should be combined to produce better educational environment to build knowledgebased society.

\section{REFFERENCES}

Anderson, C. (1997). Enabling and Shaping Understanding through Tutorials. In Marton, Ference, Dai Hounsel \& Noel Entwistle, The experience of learning: Implications for teaching and studying in higher education, Second Edition. Edinburg: Scottish Academic Press. p. 196.

Andriani, D. (2005). Internet dalam pendidikan jarak jauh: Pemanfaatannya di Program Pascasarjana. Paper presented in National Seminar of Instructional Technology "The role of educational technology towards Learning-based Society". Jakarta: Center of Technology and Communication (Pustekkom) Ministry of National Education and Universitas Terbuka.

Dimyati, S. (2005). Blended learning and the role of ICT at Universitas Terbuka. Paper presented in the discussion of "Utilization of ICT for Universitas Terbuka", December 2005, Jakarta: Universitas Terbuka.

Eduard A.S., Teuku, Lintang Patria \& Unggul Utan Sufandi (2005). Penggunaan teknologi informasi dalam proses pembelajaran di Universitas Terbuka. Paper presented in the discussion of "Utilization of ICT for Universitas Terbuka", December 2005, Jakarta: Universitas Terbuka. 
Gagne, R.M. (1977). The condition of learning, Third Edition. New York: Holt, Reinhart and Winston. p.285.

Gagnon Jr., G.W., \& Collay, M. (2001). Designing for learning: Six elements in constructivist classrooms. Thousand, CA: Corwin Press. Inc. pp. 7-10.

Hamied, F.A. (2005) Kerjasama lintas sektoral dan lembaga dalam pengembangan SDM. Paper presented in National Seminar of Instructional Technology "The role of educational technology towards learning-based Society". Jakarta: Center of Technology and Communication (Pustekkom) Ministry of National Education and Universitas Terbuka.

Hardhono, A.P. (2005). Aplikasi teknologi untuk Universitas Terbuka. Paper presented in the discussion of "Utilization of ICT for Universitas Terbuka", December 2005, Jakarta: Universitas Terbuka.

Hong-Ki-Hyung. (retrieved 12/7/2005). Lifelong learning in the Knowledge-based Society: Issues and lesson in Korea. Seoul: Keynote speech in International Seminar "Making lifelong learning a reality". Seoul: KRIVET and IIPE/UNESCO. p.1.

Ismarwati, A., Kastolan, Suroyo, \& Cahyono, P. (2005). Paper presented in National Seminar of Instructional Technology "The role of educational technology towards learningbased society". Jakarta: Center of Technology and Communication (Pustekkom) Ministry of National Education and Universitas Terbuka. p. 14.

Khvilon, E. \& Patru, M. eds. (2002). Information and Communication Technologies in teacher education-A planning guide. Paris: Division of Higher Education UNESCO, 14-15.

Knowledge Society -Homepage (2000). Lisbon: Employment and Social Affairs-Knowledge Society. p.1 http://europa.eu.int/comm/employment_social/knowledge_society/index_en.htm

Lefrancois, G.R. (1995). Theories of human learning: Kro's Report $3^{\text {rd }}$ Edition, Kro 59 and the Koron Space Exploration Department Division of Behavioral Science. pp. 317-326.

More, M.G . (2003). This book in brief: Overview. In M.G. More \& W.G. Anderson. eds. Handbook of distance education. New Jersey: Lawrence Erlbaum Associates, Inc., Publishers, pp. xiii-xiv.

Muthusamy, K. \& Fadzil, M. (2005).Criteria's for E-learning delivery platform (ELDP) for OPRN and distance learning. AAOU Journal "Networking and partnership for strengthening collaboration in open and distance education". Jakarta: Asian Association of Open Universities-Universitas Terbuka, Indonesia. pp. 13-19.

Oldknow, A. \& Taylor, R. (2003). Teaching Mathematics: Using Information and Communications Technology, $2^{\text {nd }}$ Edition, London: Continuum.

Romiszowski, A.J. \& Mason, R. (1996). Computer-mediated communication. In D.H. Jonnassen, ed. (1996). Handbook of research for educational communications and technology, A Project of AECT, New York, NJ: Simon \& Schuster Macmillan. p. 438.

Salmon, G. (2000). E-moderating: The key to teaching and learning online. London: Kogan Page Limited. p. 3.

Salmon, G. (2004). E-moderating: The key to teaching and learning online, $2^{\text {nd }}$ Edition. http://www.atimod.com/e-moderating/shtml

Suryadi, A. (2005). Reformasi sistem pembelajaran. Paper presented in National Seminar of Instructional Technology "The role of educational technology towards learning-based 
society". Jakarta: Center of Technology and Communication (Pustekkom) Ministry of National Education and Universitas Terbuka. p. 1.

Suroyo, A.I., Kastolan \& Cahyono, P. (2005). Applikasi ICT dalam pendidikan dan pelatihan menghadapi Ujian Akhir Nasional, Studi Kasus: Bidang Studi Matematika SMA/MA. Paper presented in National Seminar of Mathematics and Natural Sciences "Development of education and research in Mathematics and natural sciences based on Information and Communication Technology". Surabaya: Universitas Negeri Surabaya. p. 9.

Svensson, L. (1997). Skill in learning and organizing knowledge. In Marton, H. \& Entwistle eds. (1997). The experience of learning: Implications for studying in higher education, Second Edition. Edinburgh: Scottish Academic Press Limited.

Tutorial Online Technical Guidance for Tutors (2005). Jakarta: Universitas Terbuka.p.9.

Towards a Knowledge-based Society - in Europe, Europe in 12 lessons.

http://europa.eu.int/abc/12lessons/index8_en.htm 